\begin{tabular}{rr} 
çağdaş & Yaratıcı Drama Dergisi 2016, 11(1), 71-88 \\
drama & www.yader.org \\
\hline
\end{tabular}

\title{
Yaratıcı Drama Yönteminin İlkokul İkinci Sınıf Öğrencilerinin Türkçe Dersine İlişkin Tutumlarına Etkisii*
}

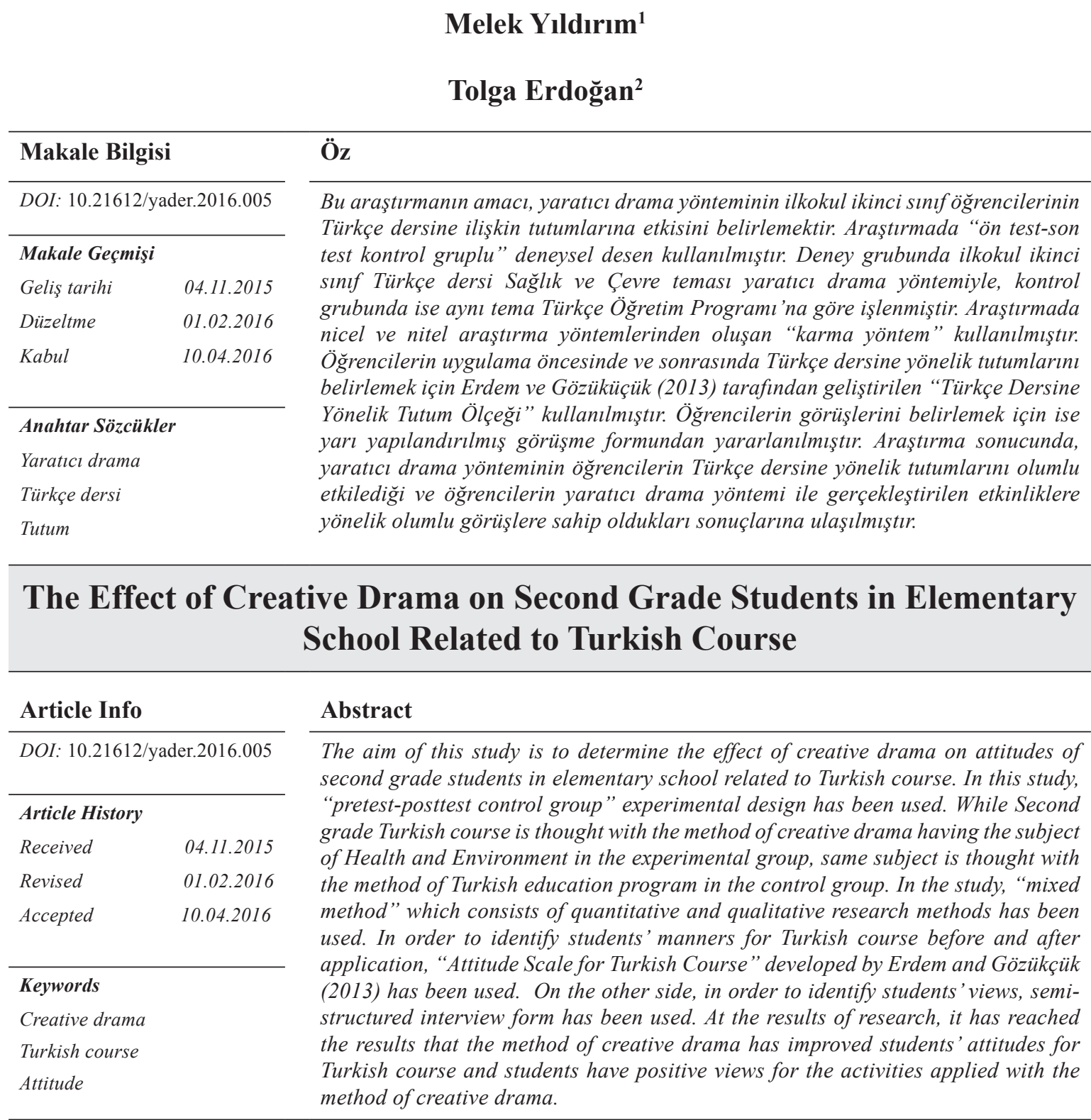

Bu çalışma MEB Özel Doğaç Yaratıcı Drama Liderliği Projesi’nden geliştirilmiştir.

1 Sınıf Öğretmeni, Mehmet Koçar İlkokulu, E-posta: melekyıldırım48@ gmail.com.

2 Doç. Dr., Karadeniz Teknik Üniversitesi, Sınıf Öğretmenliği Ana Bilim Dalı, E-posta: tolgaerdogan.edu@gmail.com 


\section{Giriş}

Türkçe dersi öğretim programı yapılandırmacı yaklaşım temel alınarak hazırlanmıştır. Yapılandırmacı yaklaşımda, öğrenci merkezli bir anlayış söz konusudur. Öğrenci yeni bilgileri var olan bilgileriyle ilişkilendirir ve bilgiyi kendisi yapılandırır. Bu yapılandırma sürecinde öğrenci aktif rol alır. Yapılandırmacı yaklaşıma dayalı öğrenme ortamlarında bilgi öğrenciye doğrudan sunulmaz. Öğrencinin bilgiyi yapılandırması için uygun öğrenme-öğretme süreçleri öğretmen tarafindan oluşturulur. Bu süreçte öğretmen rehberdir ve öğrencinin bilgiyi yapılandırma sürecinde ona yol gösterir.

Türkçe Öğretim Programı'nda yapılandırmacı yaklaşım merkeze alınarak çoklu zekâ, öğrenci merkezli öğrenme, beyin temelli öğrenme, bireysel farklılıklara duyarlılık, sarmal ve tematik yaklaşım, beceri yaklaşımı, yapılandırmacı okuma, anlama ve yazma öğretimi modelleri gibi çeşitli yaklaşım ve modellerden yararlanılmıştır. Programda Türkçe öğretimi içeriğinde sadece dinleme, konuşma, okuma, yazma, görsel okuma ve görsel sunu gibi dil becerilerinin geliştirilmesi değil, aynı zamanda düşünme, anlama, sıralama, sınıflama, sorgulama, ilişki kurma, eleştirme, analiz-sentez yapma ve değerlendirme gibi zihinsel becerilerinin geliştirilmesi de ele alınmıştır (Güneş, 2009). Ayrıca programda öğrencilerin Türkçeyi seven, okumaktan ve öğrenmekten zevk alan bireyler olarak yetiştirilmesi amaçlanmaktadır (MEB, 2009).

Yapılandırmacı öğrenme sürecine dayalı bir Türkçe öğretiminde öğretmen, öğrencilerin bireysel farkl1lıklarına uygun seçenekler sunar, yönergeler verir ve her öğrenenin kendi kararını kendisinin vermesine zemin oluşturmaktadır. Öğretmen, bireye uygun etkinlikler oluşturma, öğrencilerin hem birbirleri ile hem de kendisi ile iletişim kurmalarını cesaretlendirme, işbirliğini teşvik etme, öğrenenlerin fikir ve sorularını açıkça ifade edecekleri ortamları oluşturma gibi rolleri yerine getirir (Brooks ve Brooks, 1998).

İlkokul Türkçe Öğretim Programı'nın temel aldığı yapılandırmacı yaklaşıma uygun öğrenme ortamları oluşturulabilmesi için bu yaklaşıma uygun öğretim yöntemlerinin kullanılması gerekir (Erdoğan, 2011). Yapılandırmacı yaklaşıma uygun olan problem çözme, örnek olay incelemesi, yaratıcı drama, rol yapma, dramatizasyon, proje çalışması, beyin firtınası ve altı şapka düşünme tekniği öğrenciyi, öğrenme sürecine aktif olarak katarak eski bilgileri üzerine yeni bilgilerin inşa etmelerine olanak sağlayan yöntem ve tekniklerdir. Bu yöntemler içerisinde yapılandırmacı yaklaşıma uygun öğrenme sürecini etkili kılabilecek yöntemlerden biri yaratıcı dramadır (Aykaç ve Ulubey, 2008).

Adıgüzel (2006) yaratıcı dramayı, bir grupla veya grup üyelerinin yaşantılarından yola çıkarak, bir amacın, düşüncenin, doğaçlama, rol oynama (rol alma) vd. tekniklerden yararlanılarak canlandırılması olarak tanımlar. Bu canlandırma süreçleri deneyimli bir lider/eğitmen eşliğinde yürütülürken kendiliğindenliğe (spontaniteye), şimdi ve burada ilkesine, -mış gibi yapmaya dayalıdır ve yaratıcı drama, oyunun genel özelliklerinden doğrudan yararlanır.

Yaratıcı drama, her yaş grubuna dönük olarak her mekânda uygulanabilir. Bu uygulamalar zorunlu bir donanıma, araç ve gerece, metne dayalı değildir. Yaratıcı dramanın gerçekleşebilmesi için önce bir gruba, yaratıcı drama alanıyla ilgili yeterli bilgi ve deneyime sahip bir lidere/eğitmene, grubun rahatça kullanabileceği bir mekâna ve grubun canlandırma yapabileceği dramatik yapıya sahip bir düşünceye gereksinim vardır (Adıgüzel, 2010). 
Yaratıcı drama sürecinde öğrenciler, konuların öğrenilmesine etkin olarak katılarak kendi yaptığıla öğrenirken diğer yandan duyu organlarını harekete geçirerek olay ya da durumları yaşamaktadır (Üstündağ, 2004). Yaratıcı drama etkinlikleri, karar verme becerisini ve duyusal farkındalığı geliştirir. Yaratıcı drama çalışmalarının doğasında olan yoğun insan etkileşimiyle gerçekleşen çalışmalar katılımcıları gerçek yaşam durumlarına hazırlar. Drama genel anlamda insan etkileşiminin tüm çeşitlerini içerir (Furman, 1990).

Drama, çocukların insanlarla daha doğru iletişim kurmalarını sağlar. Anlamayı, şefkati, farkındalığı ve başkalarına saygılı olmayı geliştirir. Farklı karakterlere girerek değerleri ve duyguları keşfetmeye yarar. Böylece farklı duygulara yönelik deneyim elde etme şansı sunar. Drama sürecinde rolün içinde olmak empati becerisinin gelişmesini destekler ve çocukların diğer insanların durumlarını ve bakış açılarını anlamalarına yardım eder. Bu sayede öğrenciler bir olayın farklı nedenlerinin ve sonuçlarının olabileceğini ve herkesin aynı duruma farklı tepki verebileceğini anlarlar. Başka kişilerin olaylar karşısında nasıl düşündüklerini yaşayarak öğrenmiş olurlar (Arieli, 2007; Baldwin, 2009; Baldwin, 2008).

Yaratıcı drama sürecinde önceden belirlenen kazanımlara, etkinliklerin planlı ve programlı bir şekilde yürütülmesiyle ulaşılır. Belirlenen kazanımlar çerçevesinde yürütülen etkinliklerde yaratıcılık ve şimdi-burada ilkeleri ile hareket edilir; ancak her bir aşamada sorgulamaya ve çözüm üretmeye giden yollar izlenir. Adıgüzel (2010), yaratıcı drama çalışmalarının belirli aşamalar içerisinde gerçekleştirileceğini belirtir. Bu çalışmalarda ne, niçin, ne zaman, nasıl, nerede, kim, kime (kimlerle) gibi sorulara verilecek yanıtlar, yaratıcı drama sürecinin tüm yapılandırmasını ya da izlenecek aşamalar zincirini oluşturur.

Türkçe dersinde anlama ve anlatma becerilerinin uygulamalarla geliştirilmesinde yaratıcı drama etkin bir yöntem olarak kullanılabilir. Yaratıcı drama, öğrencinin anlama ve anlatma yeteneklerini, kişiliğini daha çok geliştirebilir. Türkçe de her şeyden önce bir anlama ve anlatma dersi olduğuna göre, yaratıcı dramanın bir öğretim yöntemi olarak önemi kolayca anlaşılabilir (Aykaç, 2011). Erdoğan'a (2013), göre de yaratıcı drama; yapısı, aşamaları ve özellikleriyle yapılandırmacı yaklaşımı temel alan Türkçe öğretim programının amaçlarına ulaşmasında kullanılabilecek etkili bir yöntemdir. Yaratıcı drama sürecinde bireyler yaptıkları etkinlikler yoluyla dinleme, konuşma, okuma ve yazma becerilerini kazanabilir ve geliştirebilirler. Yaratıcı drama çalışmaları hazırlık/ ısınma, canlandırma ve değerlendirme çalışmalarıyla dil becerilerinin geliştirilmesi için uygun eğitim ortamları yaratılmasını sağlar.

Türkçe dersinde yaratıcı drama yöntemiyle yapılan etkinlikler, öğrencilerin hem dil becerilerini istenilen nitelikte kazanmalarını hem de derse karşı olumlu tutum geliştirmelerini sağlar. Yapılan araştırmalar da yaratıcı drama yönteminin katılımcıların dil becerilerini geliştirmede etkili olduğunu ve bu becerilere yönelik tutumlarını geliştirdiğini ortaya koymaktadır (Ataman, 2006; Aykaç, 2011; Karateke, 2006; Kaya, 2008; Kırmızı, 2008; Stowe, 2001; Yılmaz, 2008).

Dil becerileri bir bütün olarak gelişir. Dinleme, konuşma, okuma, yazma, görsel okuma ve görsel sunu becerilerinin gelişimi birbirleriyle ilişkilidir ve bu becerilerin hiçbiri tek başına gelişmez. Yaratıcı drama sürecinde yapılan etkinliklerde öğrenciler dilin bu becerilerini birlikte geliştirirler. Yaratıcı drama, dil becerilerinin birbiriyle etkileşimi için yaratıcı ve bütünsel bir araçtır (Annarella, 2000). 
Dil becerileri doğal bir ortam içinde gelişir. Dil kullanımını gerektiren gerçek ortamların yanı sıra eğitimde gerçeğe benzer bağlamlar yaratarak dil kullanımlarını çeşitlendirmenin bir yolu da yaratıcı drama uygulamalarıdır. Yaratıcı drama, doğal ortamlarıyla dil gelişimi için çocuklara katkı sağlar. Yaratıcı drama sürecindeki canlandırmalar sırasında çocuklar anlaşmak için birbirlerini dinlemeye ve daha dikkatli konuşmaya ihtiyaç duyarlar (Aktaş Arnas, Cömertpay ve Sofu, 2007).

Öğrencilerin Türkçe Öğretim Programı'nda belirtilen dil becerilerini etkili bir şekilde kazanmalarında Türkçe dersine ilişkin oluşturdukları tutumlar önemli rol oynar. Tutum, bireyin herhangi bir olay, durum, nesneyi olumlu veya olumsuz bir şekilde algıladığı düşünce biçimidir. Bir olay, durum, nesneye ilişkin duygu, düşünce ve davranışlar, ona karşı tutumu etkiler. Aynı şekilde; bir olay, durum, nesneye ilişkin tutumlar da ona ilişkin duygu, düşünce ve davranışları etkiler. Tutum ve davranışlar birbirinden ayrılmazlar (Maio ve Augoustinos, 2005). Olumlu tutumlar öğrenme sürecinde öğrencileri daha başarılı kılarken, olumsuz tutumlar başarısızlığa neden olabilmektedir. Yapılan araştırmalar dil öğrenme sürecinde tutumun önemli olduğunu ve dikkate alınması gerektiğini ortaya koymaktadır (Erdem ve Gözüküçük, 2013). Bu noktadan hareketle öğrencilerin Türkçe derslerinde dil becerilerini istenilen nitelikte kazanabilmeleri için derse karşı olumlu tutuma sahip olmaları gerektiği söylenebilir.

\section{Araştırmanın Amacı}

$\mathrm{Bu}$ araştırmanın amacı, yaratıcı drama yönteminin ilkokul ikinci sınıf öğrencilerinin Türkçe dersine ilişkin tutumlarına etkisini belirlemektir. Ayrıca araştırmada öğrencilerin yaratıcı drama yöntemiyle gerçekleştirilen etkinliklere ilişkin görüşlerinin belirlenmesi de amaçlanmıştır. Araştırmada bu amaca ulaşmak için aşağıdaki sorulara yanıt aranmıştır:

1. Deney grubundaki öğrencilerin Türkçe dersi tutum ölçeği ön test ve son test puanları arasında anlamlı bir fark var midır?

2. Kontrol grubundaki öğrencilerin Türkçe dersi tutum ölçeği ön test ve son test puanları arasında anlamlı bir fark var midır?

3. Deney ve kontrol grubundaki öğrencilerin Türkçe dersi tutum ölçeği son test puanları arasında anlamlı bir fark var midır?

4. Deney grubundaki öğrencilerin yaratıcı drama yöntemiyle gerçekleştirilen etkinliklere ilişkin görüşleri nelerdir?

\section{Yöntem}

\section{Araştırmanın Modeli}

Araştırmada "ön test-son test kontrol gruplu” deneysel desen kullanılmıştır. Araştırma iki sınıfta gerçekleştirilmiştir. Deney grubunda ilkokul ikinci sınıf Türkçe dersi Sağlık ve Çevre teması yaratıcı drama yöntemiyle, kontrol grubunda ise aynı tema Türkçe Öğretim Programı'na göre işlenmiştir. Araştırmada kullanılan deneysel desen şu şekilde gösterilebilir:

Tablo 1. Araştırmada Kullanılan Deneysel Desen

\begin{tabular}{cccc}
\hline G1 & T1 & Deney (Yaratıc Drama Yöntemi) & T1 \\
G2 & T1 & Kontrol (Türkçe Öğretim Programına Göre Yapılan Öğretim ) & T1 \\
\hline
\end{tabular}


Araştırmada elde edilen verilerin toplanması, analizi ve yorumlanmasında nicel ve nitel araştırma yöntemlerinden oluşan "karma yöntem" kullanılmıştır. Karma yöntemde, nicel ve nitel yöntemler birlikte kullanılarak araştırma problemi ve soruları daha ayrıntılı bir şekilde incelenir (Cresswell, 2008; Fraenkel ve Wallen, 2006). Bu yöntemin en önemli özelliği, araştırma sonuçlarının nicel verilerle gösterilmesinin yanı sıra nitel verilerle de niçin bu sonuçların elde edildiğinin açıklanmasına imkân tanımasıdır (McMillan ve Schumacher, 2006).

Karma yöntem; zenginleştirilmiş (triangulation), açıklayıcı (explanatory) ve keşfe yönelik (exploratory) desen olmak üzere üçe ayrılmaktadır. Bu araştırmada "zenginleştirilmiş desen" kullanılmıştır. Zenginleştirilmiş desende nicel ve nitel veriler eş zamanlı toplanır. Daha sonra bu verilerin birbirini destekleyip desteklemediği incelenerek veriler karşılaştırılır. Elde edilen veriler bu karşılaştırmaya göre yorumlanır (Büyüköztürk, Çakmak, Akgün, Karadeniz ve Demirel, 2009; Fraenkel ve Wallen, 2006). Araştırmada, nicel veri toplama aracı olarak "Türkçe Dersine Yönelik Tutum Ölçeği”, nitel veri toplama aracı olarak "yarı yapılandırılmış görüşme formu" ndan yararlanılmıştır.

Araştırmada kullanılan zenginleştirilmiş desen şu şekilde gösterilebilir (Cresswell ve PlanoClark, 2007):

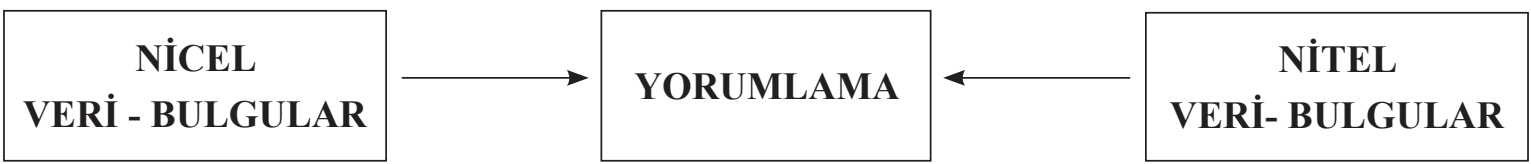

Şekil 1. Araştırmada Kullanılan Zenginleştirilmiş Desen

\section{Çalışma Grubu}

Araştırma, 2013-2014 eğitim-öğretim yılı ikinci döneminde Muğla ili, Kavaklıdere İlçesi'ndeki bir ilkokulda gerçekleştirilmiştir. Araştırmanın deney grubunu ilgili okulun ikinci sınıfinda öğrenim gören 22, kontrol grubunu ise diğer bir sınıftaki 14 öğrenci oluşturmaktadır. Araştırmacı tarafindan deney grubundaki öğrencilere çalışmanın amacı ve içeriği ile ilgili bilgi verilmiştir. Deney grubundaki 22 öğrencinin 10’u erkek, 12'si kı, kontrol grubundaki öğrencilerin ise 10’u erkek, 4'ü kızdır. Öğrencilerin yaşları 7-8 arasındadır. Öğrenciler daha önce drama eğitimi almamışlardır.

Araştırmada, uygulama öncesinde deney ve kontrol grubundaki öğrencilerin Türkçe dersine yönelik tutumlarının denk olup olmadığını belirlemek amacıyla tutum ölçeği uygulanmıştır. Öğrencilerin ölçekten aldıkları ön test puanlarının sıra ortalaması ve sıra toplamları hesaplanmış ve sıra ortalamaları arasında istatistiksel olarak anlamlı bir fark olup olmadığ $\breve{1}_{1}$ Mann Whitney U testiyle analiz edilmiştir. Deney ve kontrol grubundaki öğrencilerin sıra ortalamaları arasında anlamlı bir fark olup olmadığına ilişkin sonuçlar Tablo 2'de verilmiştir.

Tablo 2. Deney ve Kontrol Grubundaki Öğrencilerin Türkçe Dersine Yönelik Tutum Ölçeğinden Aldıkları Ön Test Puanlarına İlişkin Mann Whitney U Testi Sonuçları

\begin{tabular}{llllll}
\hline Konuşma & $\mathrm{N}$ & Sira ortalamas1 & Sira toplam1 & $\mathrm{U}$ & $\mathrm{p}$ \\
\hline Deney & 21 & 20.64 & 433.50 & 91.50 & 0.61 \\
Kontrol & 14 & 14.04 & 196.50 & & \\
\hline $\mathrm{p}>.05$ & & & & &
\end{tabular}


Tablo 2'deki veriler, deney grubundaki öğrencilerin sıra ortalamasının 20.64, kontrol grubundaki öğrencilerin ise 14.04 olduğunu göstermektedir. Araştırmada elde edilen bu bulgu, deney ve kontrol grubundaki öğrencilerin uygulama öncesinde Türkçe dersine yönelik tutumları arasında anlamlı bir fark olmadığını ortaya koymaktadır $(U=91.50, \mathrm{p}>.05)$. Başka bir deyişle deney ve kontrol grubundaki öğrencilerin uygulamanın başında Türkçe dersine yönelik tutum açısından denk olduğu görülmektedir. Bu sonuca göre deney ve kontrol grubu öğrencilerinin çalışmaya benzer düzeyde başladıkları söylenebilir.

\section{Uygulama Süreci}

Araştırmanın uygulaması için ilk olarak ilkokul ikinci sınıf Türkçe dersi Sağlık ve Çevre temasına yönelik kitap havuzu oluşturulmuştur. Havuzda yer alan kitaplar için Muğla Şehbal Hilmi Şerif Baydur Çocuk Kütüphanesi’nden, ilde bulunan kitapçılardan ve internette yer alan sitelerden (kitapyurdu.com, pandora.com, kitapkurdu.com) yararlanılmıştır. Daha sonra araştırmacılar tarafindan bu kitaplardan dört tanesi seçilmiştir. Araştırma için seçilen kitaplar; Bumba Dağın Arkasını Merak Ediyor (Cem Akkaş), Doğanın Öfkesi (Gülsüm Cengiz), Ormandaki Apartman (Aytül Akal) ve Koca Dev'in Koca Sebzeleri (Banu Bozdemir)'dir. Uygulama için kitaplar belirlendikten sonra araştırmacılar tarafından bu kitaplardan yola çıkılarak Türkçe dersi "Sağlık ve Çevre" teması ile programdaki kazanımlara yönelik yaratıcı drama yöntemiyle oturumlar hazırlanmıştır. Hazırlanan oturumlar yaratıcı drama yöntemine uygun olarak hazırlık/ısınma, canlandırma ve değerlendirme/ tartışma aşamalarından oluşmuştur.

Araştırmanın uygulaması 3 hafta sürmüştür. Araştırmada üç hafta boyunca toplam 24 saat uygulama yapılmıştır. Uygulamada her kitaba yönelik yaratıcı drama yöntemiyle toplam 6 saatlik oturum uygulanmıştır. Her kitaba yönelik uygulamalar 3'er saatlik iki oturum şeklinde gerçekleştirilmiştir.

Araştırmanın uygulaması, okulun çok amaçlı salonu ve deney grubunun sınıfında yapılmıştır. Uygulamanın yapıldığı salon 26 m. x 14 m. büyüklügünde olup zemini karo taştır. Salon büyük pencerelere sahip olup aydınlıktır. Çalışma salonunda bir sahne vardır. Sınıf ise $24 \mathrm{~m} 2$ olup sınıfta bilgisayar ve ses sistemi, yazı tahtası, malzeme dolabı, masa gibi araç ve gereçler bulunmaktadır.

\section{Veri Toplama Araçları}

Tutum Ölçeği: Bu araştırmanın nicel verileri için Erdem ve Gözüküçük (2013) tarafından geliştirilen "Türkçe Dersine Yönelik Tutum Ölçeğii” kullanılmıştır. Ölçek 20 maddeden ve likert türünde 3 seçenekten oluşmaktadır. İlkokul 2. sınıf öğrencilerinden, her maddenin karşısında bulunan " $3=$ kat1liyorum", "2= Kısmen katıliyorum" ve " $1=$ katılmıyorum” seçeneklerinden birinin işaretlenmesi istenmiştir. Katılma derecesi $\operatorname{aralıkları}(n-1: n)$ formülü kullanılarak bulunmuştur. Hesaplama sonucu 1 ile 3 arasındaki aralık genişliği 0.66 olarak belirlenmiştir. Ankette yer alan olumlu maddelerin katılma düzeyleri için sınırlar; 1.00-1.66 "katılmıyorum", 1.67-2.33 "Kısmen katılıyorum" ve " 2.34-3.00 "katılıyorum" olarak yorumlanmıştır. Bunun yanısıra ölçekte 10 olumlu, 10 olumsuz madde yer almaktadır. Olumsuz maddeler değerlendirme aşamasında ters çevrilerek kodlanmıştır.

Görüşme Formu: Görüşme tekniği, araştırmacının araştırma konusuyla ilgili olarak derinlemesine bilgi edinebileceği, önceden hazırladığı görüşme formuna bağlı kalarak ek sorular sorma esnekliği ile hareket edebileceği bir veri toplama tekniğidir (Yıldırım ve Şimşek, 2006). 
Araştırmacı tarafından yapılan çalışmalara yönelik olarak katılımcıların görüşlerini belirlemek için bir görüşme formu geliştirilmiştir. Bu formun geliştirilmesinde alan yazında yer alan örnek formlar dikkate alınarak sorular hazırlanmıştır. Yapılacak görüşme için araştırmacı tarafından yarı yapılandırılmış görüşme formuna son hali verilmiştir. 5'erli ve 6'şarlı öğrenci grupları ile odak grup görüşmesi şeklinde yapılan görüşme toplam 21 öğrenci ile gerçekleştirilmiştir.

\section{Verilerin Analizi}

\section{Nicel Verilerin Analizi}

Araştırmada kullanılan “Türkçe Dersine Yönelik Tutum Ölçeği”, 10'u olumlu ve 10’u olumsuz olmak üzere 20 maddeden oluşmaktadır. Ölçekteki her tutum ifadesi için "Katılıyorum", "Kısmen Katılıyorum”, ve "Katılmıyorum” düzeyleri kullanılmıştır. Tutum ölçeğinde yer alan tutum ifadeleri için olumlu maddelerde "Katılıyorum" 3, "Kısmen Katılıorum" 2, "Katılmıyorum" 1 olarak puanlandırılmıştır. Olumsuz ifadelerde ise bunun tersi puanlama yapılmıştır "Katılıyorum” 1, "Kısmen Katıliyorum" 2, "Katılmıyorum" 3 olarak puanlanmıştır.

Tutum ölçeği uygulamanın başında ve sonunda deney ve kontrol grubundaki öğrencilere uygulanmıştır. Deney ve kontrol grubundaki öğrencilerin Türkçe dersine yönelik tutum ölçeği ön test puanları arasında anlamlı bir fark olup olmadığını belirlemek için "Mann Whitney U" testi kullanılmıştır. Deney ve kontrol grubundaki öğrencilerin tutum ölçeği ön test ve son test puanları arasında anlamlı bir fark olup olmadığı Wilcoxon İşaretli Sıralar Testiyle belirlenmiştir. Uygulama sonrasında deney ve kontrol grubundaki öğrencilerin Türkçe dersine yönelik tutum ölçeği son test puanları arasında istatistiksel olarak anlamlı bir fark olup olmadığ 1 ise yine Mann Whitney U testiyle analiz edilmiştir. Yapılan analiz sonuçları tablolar şeklinde bulgular bölümünde sunulmuştur.

\section{Nitel Verilerin Analizi}

Araştırma sonunda deney grubundaki öğrencilerle araştırmacı tarafından odak grup görüşmesi yoluyla yarı yapılandırılmış görüşmeler yapılmıştır. Yapılan görüşmeler kameraya kaydedilmiştir. Daha sonra kaydedilen görüntüler düz metin haline getirilmiştir. Görüşmelerde elde edilen veriler de betimsel analiz tekniğiyle incelenerek katılımcıların sorulara yönelik görüşleri ortaya konulmuştur. Ayrıca görüşmelerde elde edilen bulgular, katılımcıların sorulara ilişkin verdiği cevaplardan aynen alıntılar yapılarak desteklenmiştir.

Betimsel analizde veriler daha önceden belirlenen temalara göre özetlenir ve yorumlanır. Ayrıca verilerin sunulmasında araştırma sorularının ortaya koyduğu temalar dikkate alınabileceği gibi, görüşme ve gözlem sırasında kullanılan sorular veya boyutlar da dikkate alınabilir. Betimsel analizde görüşülen ya da gözlenen bireylerin görüşlerini çarpıcı bir biçimde yansıtmak amacıyla doğrudan alıntılara sık sık yer verilir (Yıldırım ve Şimşek, 2006). 


\section{Bulgular ve Yorum}

\section{Nicel Bulgular ve Yorum}

\section{Deney Grubundaki Öğrencilerin Türkçe Dersi Tutum Ölçeği Ön Test ve Son Test Puanları}

Araştırmada, tutum ölçeği uygulama öncesinde ön test, uygulama sonrasında ise son test olarak uygulanmıştır. Deney grubundaki öğrencilerin tutum ölçeği ön test ve son test puanları arasında anlamlı bir fark olup olmadığ 1 Wilcoxon İşaretli Sıralar Testiyle analiz edilmiştir. Deney ve kontrol grubundaki öğrencilerin puanları arasında anlamlı bir fark olup olmadığına ilişkin sonuçlar Tablo 3 'te verilmiştir.

Tablo 3. Deney Grubundaki Öğrencilerin Türkçe Dersine Yönelik Tutum Ölçeğinden Aldıkları Ön Test ve Son Test Puanlarının Wilcoxon Işsaretli Siralar Testi Sonuçları

\begin{tabular}{llllll}
\hline (Son test-Ön test) & $\mathbf{N}$ & Sıra ortalaması & Sıra toplamı & $\mathbf{z}$ & $\mathbf{p}$ \\
\hline Negatif Sıra & 2 & 3.75 & 7.50 & $3.64^{*}$ & .000 \\
Pozitif Sıra & 18 & 11.25 & 202.50 & & \\
Eşit & 1 & - & - & & \\
\hline
\end{tabular}

Tablo 3'teki verilere göre, deney grubundaki öğrencilerin ön test ve son test puanları arasında anlamlı bir fark olduğu görülmektedir $(\mathrm{z}=3.64, \mathrm{p}<.05)$. Araştırmada elde edilen bu bulgu, yaratıcı drama yönteminin öğrencilerin Türkçe dersine yönelik tutumlarını olumlu etkilediğini ortaya koymaktadır. Deney grubu öğrencilerinin sınıfında yaratıcı drama yöntemi ile işlenen Türkçe dersinin, öğrencilerin Türkçe dersine yönelik tutumunu anlamlı derecede arttırdığı ortaya çıkmıştır.

\section{Kontrol Grubundaki Öğrencilerin Türkçe Dersi Tutum Ölçeği Ön Test ve Son Test Puanları}

Kontrol grubundaki öğrencilerin tutum ölçeği ön test ve son test puanları arasında anlamlı bir fark olup olmadığı Wilcoxon İşaretli Sıralar Testiyle analiz edilmiştir. Deney ve kontrol grubundaki öğrencilerin puanları arasında anlamlı bir fark olup olmadığına ilişkin sonuçlar Tablo 4’te verilmiştir.

Tablo 4. Kontrol Grubundaki Öğrencilerin Türkçe Dersine Yönelik Tutum Ölçeğinden Aldıkları Ön Test ve Son Test Puanlarının Wilcoxon İsaretli Sıralar Testi Sonuçları

\begin{tabular}{llllll}
\hline (Son test-Ön test) & $\mathrm{N}$ & Sıra ortalaması & Sira toplamı & $\mathrm{z}$ & $\mathrm{p}$ \\
\hline Negatif Sıra & 4 & 5.13 & 20.50 & 1.45 & .146 \\
Pozitif Sıra & 8 & 7.19 & 57.50 & & \\
Eşit & 2 & - & - & & \\
\hline
\end{tabular}

Tablo 4'teki verilere göre, kontrol grubundaki öğrencilerin ön test ve son test puanlar1 arasında anlamlı bir fark olmadığı görülmektedir $(z=1.45, \mathrm{p}>.05)$. Araştırmada elde edilen bu bulgu, Türkçe öğretim programına göre yapılan öğretimin öğrencilerin Türkçe dersine yönelik tutumlarını geliştirmediğini göstermektedir. 


\section{Deney ve Kontrol Grubundaki Öğrencilerin Türkçe Dersi Tutum Ölçeği Son Test Puanları}

Deney ve kontrol grubundaki öğrencilerin tutum ölçeğinden aldıkları son test puanları arasında istatistiksel olarak anlamlı bir fark olup olmadığı Mann Whitney U testiyle analiz edilmiştir. Deney ve kontrol grubundaki öğrencilerin sıra ortalamaları arasında anlamlı bir fark olup olmadığına ilişkin sonuçlar Tablo 5'te verilmiştir.

Tablo 5. Deney ve Kontrol Grubundaki Öğrencilerin Türkçe Dersine Yönelik Tutum Ölçeğinde Aldıkları Son Test Puanlarına İlişkin Mann Whitney U Testi Sonuçları

\begin{tabular}{llllll}
\hline Konuşma & $\mathrm{n}$ & Sira ortalaması & Sira toplamı & U & $\mathrm{p}$ \\
\hline Deney & 21 & 22.31 & 468.50 & 56.50 & .002 \\
Kontrol & 14 & 11.54 & 161.50 & & \\
\hline $\mathrm{p}>.05$ & & & &
\end{tabular}

Tablo 5'teki veriler, deney grubundaki öğrencilerin sıra ortalamasının 22.31, kontrol grubundaki öğrencilerin ise 11.54 olduğunu göstermektedir. Araştırmada elde edilen bu bulgu, deney ve kontrol grubundaki öğrencilerin uygulama sonrasında Türkçe dersine yönelik tutumları arasında deney grubu lehine anlamlı bir fark olduğunu ortaya koymaktadır $(U=56.50, p<.05)$. Başka bir deyişle, yaratıcı drama yönteminin Türkçe Öğretim Programı'na göre yapılan öğretime göre öğrencilerin Türkçe dersine yönelik tutumunu geliştirmede daha etkili olduğu görülmektedir.

\section{Nitel Bulgular ve Yorum}

\section{Öğrencilerin Türkçe Temalarının Daha Önceki Yöntem ve Tekniklerle veya Yaratıcı Drama Yöntemi ile İşlenmesine İlişkin Görüşleri}

Öğrenci görüşlerinden elde edilen veriler incelendiğinde, öğrencilerin Türkçe temalarını yaratıcı drama yöntemi ile işlemeyi tercih ettikleri görülmüştür. Öğrenciler, daha önceki ders işleme sürecindeki okuma bölümünde, -okumayı sevseler bile- sıkıldıklarını belirtmişlerdir. Sağlık ve Çevre temasının yaratıcı drama etkinlikleri ile işlenmesinde yaptıkları canlandırmalarda yaratıcılıklarını kullandıklarını, farklı rollere girmekten ve hikâyelerin kahramanları olmaktan memnun olduklarını, hikâyeleri gerçekmiş gibi oynamaktan haz aldıklarını, birçok yeni bilgi öğrendiklerini vurgulamışlardır. Yaratıı drama ile ders işlemenin okumalarını olumlu etkilediğini, kitapların ders kitaplarındaki metinlere benzemediğini, kitapların çok farklı yönlerini fark ettiklerini söylemişlerdir. Yaratıcı drama ile ders işlenirken zamanın hızla geçtiğini, eğlendiklerini ve oyun oynamaktan zevk aldıklarını belirtmişlerdir. Konuyla ilgili 1. ve 8. katılımcılar görüşlerini şu şekilde ifade etmişlerdir:

K 1: Yaratıcı drama ile işlemeyi tercih ederim. Çünkü hem okumamızı geliştirmemizi sağlıyor hem de derslerimizde eğleniyoruz.

K 8: Yaratıcı drama. Çünkü kitapların adını, kitapların içeriğini bize farklı şekilde gösteriyor.

\section{Öğrencilerin Derslerde Daha Önce Kullanılan Yöntem ve Teknikler ile Yaratıcı Drama Arasındaki Benzerlik ve Farklılıklara İlişkin Görüşleri}

Öğrenciler, derslerde daha önce kullanılan yöntem ve tekniklerle yaratıcı dramanın birbirinden farklı olduğunu düşünmektedirler. Daha önceki derslerde yazma etkinliklerinin ağırlıkta 
olduğunu, tahtaya çıkıp aynı şeyleri yaptıklarını, süreçte soru-cevap tekniğinin kullanıldığını, hayal gücünü geliştiren etkinlikler yapılmadığını, sürekli oturarak ders işlediklerini ve derslerle oyunu birleştirmediklerini belirtmişlerdir. Yaratıcı drama ile ders işlerken farklı malzemelerle çalıştıklarını, sürekli birbirinden farklı ve şaşırtıcı etkinlikler yaptıklarını, el ele tutuşularak çember olmaktan mutlu olduklarını, okuma yaparak bunların canlandırmalara aktarıldığını, canlandırmalarda hikâyenin kahramanları olduklarını, canlandırmalar sonrasında hayal güçlerini kullanarak metinleri tamamladıklarını, çeşitli yazılar yazdıklarını, dersi oturarak değil hareket ederek geçirdiklerini ve dersi oyunlarla öğrendiklerini belirtmişlerdir. Bu konuya ilişkin 1. ve 10. katılımcıların görüşleri şu şekildedir:

K 1: Yaratıcı drama ile diğer yöntem ve teknikler birbirinden farkl. Çünkü diğer derslerde sadece kalemi kullanabileceğimiz etkinlikler yapıyoruz; ama yaratıcı drama ile ders işlerken farklı malzemeler kullanıp farklı etkinlikler yapabiliyoruz.

K 10: Diğer yöntem ve tekniklerle yaratıcı drama farklı; çünkü canlandırmalar yapmıyoruz. Metinleri biz tamamlyyoruz ve aklımıza gelen, hayal gücümüzün getirdiği şeyleri yazarak okuyoruz. Ama daha önce bunu yapmiyorduk.

\section{Öğrencilerin "Sağlık ve Çevre" Temasından Önceki Temaların İşlenmesinde Yaşadıkları Duygu ve Düşünceler}

Sağlık ve Çevre temasından önceki temaların işlenmesi sırasında öğrenciler, daha çok sıkıldıklarını ve huzursuz olduklarını ifade etmişlerdir. Derste zamanın geçmediğini, okuma görevi almadılarsa eğer -başkası okurken- çok sıkıldıklarını, derste görev alamamaktan dolayı dersin bir an önce bitmesini beklediklerini söylemişlerdir. Yazı yazmaktan hoşlanmadıklarını ve yorulduklarını vurgulamışlar, anlamadıkları konularda sorulara cevap verememekten dolayı kendilerini kötü hissetmişlerdir. Öğrencilerden bir kısmı kendini ne iyi ne de kötü hissetmiştir. Yazı yazmaktan yorulup zamanın hızlı geçmesini istediklerini; bir yandan da görev almak için istekle beklediklerini ancak bazen sıranın onlara gelmediğini belirtmişlerdir. Bazı öğrenciler de her derste yeni bir şeyler öğreniyor olmaktan mutlu olduklarını, çalışma kitabı etkinliklerini severek yaptıklarını, dersleri severek işlediklerini söylemişlerdir. Konuyla ilgili 1. ve 3. katılımcılar görüşlerini şu şekilde ifade etmişlerdir:

K 1: Önceki temalarda kendimi çok huzursuz hissediyordum, çünkü teneffüs zili çalsın diye bekliyordum. Okuma metnini okuyorduk, ama sonra başkası okurken sıklliyordum.

K 3: Sıkılıyordum, çünkü aklıma hiçbir şey gelmiyordu. Zaman hızlı geçsin istiyordum.

\section{Öğrencilerin "Sağlık ve Çevre” Temasını Yaratıcı Drama Yöntemi ile İşleme Sürecinde Yaşadıkları Duygu ve Düşünceler}

Öğrenciler, Sağlık ve Çevre temasını yaratıcı drama süreci ile işlerken mutluluk, heyecan, merak, eğlence, üzüntü, mutsuzluk ve huzur gibi birçok farklı duygu yaşamışlardır. Her derse neler yaşayacaklarını merak ederek geldiklerini ve heyecanla Türkçe dersinin gelmesini beklediklerini, her etkinlikte görev almaktan, her derste yeni bir şeyler öğrenmekten, farklı rollere girmekten dolayı mutlu olduklarını belirtmişlerdir. Yaratıcı drama ile ilk defa tanıştıklarını ve oyunlar oynayıp role girince, canlandırmalarda hangi görevi alacaklarını düşünerek heyecanlandıklarını, koşarak çok amaçlı salona gittiklerini söylemişlerdir. Daha önce birçok şeyi yanlış bildiklerini; ancak yaratıcı 
drama ile konuyu daha iyi anladıklarını, canlandırmalarla anladıklarını pekiştirdiklerini belirtmiş; her yeni kitapla birlikte meraklarının arttığını söylemişlerdir. Girdikleri bazı rollerde üzgün ve mutsuz olduklarını, Koca Dev'den korktuklarını, Doğanın Öfkesi kitabında hayvanlar, bitkiler, deniz canlıları Elvan'a kızdıkları için ve Koca Dev köylülere eziyet edince üzüldüklerini, dalgalar denizi dövünce kendilerini kötü hissettiklerini, Koca Dev'in hastalığı ile dedikodu yaparken çok şaşırdıklarını belirtmişlerdir. Bu konuyla ilgili 11. ve 12. katılımcılar görüşlerini şu şekilde ifade etmişlerdir:

K 11: Yaratıcı drama ile "Sağllk ve Çevre" konusunu öğrenirken çok eğlendim ve kendimi çok iyi hissettim. Çünkü hem oyunlar oynadık hem de hayvanlar âleminde yeni bir dünya kurduk ve orada yaşıyormuşuz gibi canlandırmalar yaptık.

K12: Yaratıcı drama ile ders işleyince kendimi çok mutlu hissediyordum. Canlandırmalarda acaba ne görev alacağız diye heyecanlanırdım. Koca Dev'in karnı ağrıdığı gün ve Koca Dev'in hastalı̆̆ hakkında dedikodu yaparken çok şaşırmışıım.

\section{Öğrencilerin Türkçe Dersinin Daha Önceki Temalarının İşılenişinde Derse Katılma Düzeyleri veya Sıklıkları}

Türkçe dersinin daha önceki temalarının işlenişinde öğrenciler, derslerden sıkıldıklarını, derse az katıldıklarını söylemişlerdir. Söz sırasının kendilerine gelmesini beklemekten sıkıldıklarını ve yorulduklarını, hep aynı tarz etkinliklerin yapıldığııı, kitaptaki etkinlikler dışında farklı bir etkinlik yapılmadığını, kitaptaki etkinlikleri yapmaktan hoşnut olmadıklarını belirtmişlerdir. Dersin kitaptaki metni okuyup anlatmak şeklinde devam ettiğini, yazı etkinliklerinin hızlıca bitmesini beklediklerini, sorulara cevap veremeyince sıkıntı yaşadıklarını ve üzüldüklerini söylemişlerdir. Bir kısım öğrenci de anlamak ve öğrenmek için derse katıldıklarını, yazı etkinlikleri kısa olunca ve resim etkinlikleri yapılacak olunca derse daha çok katıldıklarını belirtmiş̧lerdir. Bu konuya ilişkin 6. ve 11. katılımcılar görüşlerini şu şekilde ifade etmişlerdir:

K6: Türkçe ders kitabındaki etkinlikleri yapmaktan çok sıkllıyordum. Kitapta ne yazıyorsa onu okuyorduk sonra da anlatıyorduk. Derse kısmen katıllyordum. Kitaptaki okuma metinlerini okumak için bekliyordum. Ama her zaman sıra gelmiyordu. Ben okuyacağım, ben okuyacă̆ım diye konuşuyorduk ve sinıfta gürültü oluyordu.

K11: Daha önceki Türkçe derslerinde hep sıkılıyordum. Özellikle yazı yazarken yetişemiyordum ve arkadaşımdan bakmak zorunda kallyordum. Derse kısmen katıliyordum. Çünkü sorulara doğru cevap veremeyeceğim diye düşünüyordum. Az parmak kaldırlyordum.

\section{Öğrencilerin Türkçe Dersi "Sağlık ve Çevre" Temasının Yaratıcı Drama ile İşlenmesinde Derse Katılma Durumları}

Türkçe dersi "Sağlık ve Çevre" temasının yaratıcı drama ile işlenmesinde öğrenciler derse katıldıklarını ve bundan dolayı çok mutlu olduklarını belirtmişlerdir. Canlandırmalarda hep farklı rollere büründüklerini, bu rollerle birlikte kitabın içinde yer aldıklarını söylemişlerdir. Etkinliklerde tüm arkadaşlarıyla birlikte rol aldıklarını, derse katılmayan kimsenin olmadığını ve her etkinliğe istekle, zevkle katıldıklarını belirtmişlerdir. Sahneye çıkmanın kendilerini onurlandırdığını, şaşırma, korku, mutluluk, üzüntü gibi birçok duyguyu aynı anda yaşadıklarını; canlandırmalarda grupça konuşup tartışarak karar vermeden haz aldıklarını, yaratıcı drama ile ders işlerken çok mutlu 
olduklarını ve bu yüzden dersi daha iyi anladıklarını söylemişlerdir. Konuyla ilgili 4. ve 5. katılımcılar görüşlerini şu şekilde ifade etmişlerdir:

K4: Yaratıcı drama ile ders işlerken her zaman derse katıldım. Tüm arkadaşlarımız derse katıldık. Hepimiz aynı kitabı aynı anda okuduk. Sıkılmak yerine çok eğlendim ve zevk aldım. Evde ödevlerim bitince kuzenime yaratıcı dramada yaptıklarımızı anlatıyorum. Bazen akşamları birlikte ışıları kapatıp kukla oynatıyoruz. Birlikte yaratıcı drama yapıyoruz. Ben roller veriyorum, canlandirma yapıyoruz.

K5: Ben yaratıcı drama dersinde hiç sıkılmadım. Derse hep katıldım. Tüm arkadaşlarım derse katıldılar. Hiç kenarda oturan ve bekleyen kişi yoktu. Her bir kitapta neler yaptığımızı anlatabiliyorum. Bumba'yı, Koca Dev ve köylülerin hayatın canlandırmak çok eğlenceliydi.

\section{Öğrencilerin Daha Önceki Yöntem Tekniklerle veya Yaratıcı Drama Yöntemi ile Ders İşlenmesini Tercih Etme Durumları}

Öğrencilerin tamamı bundan sonraki derslerin yaratıcı drama ile işlenmesini tercih etmektedirler. Öğrenciler, yaratıcı drama ile ders işlenmesi ile dinleme, okuma, yazma ve konuşma becerilerinin geliştiğini, farklı etkinlikler yaparak sıkıldıkları yazı ve okuma etkinliklerini artık zevkle yapacaklarını, oyunlar oynayarak eğlendiklerini, hep birlikte etkinliklere katılmaktan zevk aldıklarını ve sorulara cevap verebildiklerini söylemiş̧edir. Bu konuya ilişkin 3. ve 8. katılımcılar görüşlerini şu şekilde ifade etmişlerdir:

K 3: Yaratıcı dramay tercih ederim; çünkü konuşurken eksiklerimi gördüm. Bir daha konuşurken daha çok dikkat edeceğim, yüksek sesle konuşacă̆ım ve okumaya daha çok önem vereceğim.

K 8: Yaratıcı drama ile ders işlemeyi tercih ederim; çünkü yaratıcı drama ile daha çok şey ögreniyoruz. Diğer yöntem ve tekniklerle ders işlenince daha az şey ögrreniyoruz. Aklımızda kalmıyor. Yaratıcı Drama ile sorular sorunca hemen cevabı aklımıza geliyor.

\section{Tartışma, Sonuç ve Öneriler}

Bu araştırmada, yaratıcı drama yönteminin ilkokul ikinci sınıf öğrencilerinin Türkçe dersine ilişkin tutumlarına etkisinin belirlenmesi amaçlanmıştır. Ayrıca araştırmada öğrencilerin yaratıcı drama yöntemiyle gerçekleştirilen etkinliklere yönelik görüşlerinin belirlenmesi de amaçlanmıştır. Araştırmada elde edilen sonuçlar, yaratıcı drama yönteminin öğrencilerin Türkçe dersine ilişkin tutumlarını olumlu etkilediğini ve öğrencilerin yaratıcı drama yöntemiyle gerçekleştirilen etkinliklere ilişkin görüşlerinin olumlu olduğunu ortaya koymaktadır.

Yaratıcı drama yöntemi ile işlenen Türkçe derslerinde öğrenciler, hazırlık-ısınma aşamasında yaptıkları etkinliklerle kazanımlara ulaşmak için hazırlanırlar. Yaratıcı dramayla gerçekleştirilen etkinliklerde öğrencilerin daha önceki derslerde yaptıkları gibi okuma-anlatım ve yazma etkinliklerini bir sıradanlık ve monotonluk içinde yapmak yerine, her biri birbirinden farkl1, eğlenceli ve düşünmeye dönük etkinlikler yaparlar. Her yeni kitabın olaylarına ve durumlarına farklı yönlerden bakmayı öğrenirler ve grup çalışmalarıyla sorunlara ortak çözüm üretmeye çalışırlar. Canlandırmalarda hayal güçlerini kullanarak kurgu oluştururlar ve bunu gerçekmiş gibi oynarlar. Öğrenciler, süreç içinde okumalarını geliştirmeye, dinlemenin önemini kavramaya yönelik kazanımları edinirler. 
Konuşmalarında, dinlediklerinde ve okuduklarında sebep-sonuç ilişkisi arayarak sorgulama ve eleştirel düşünme becerilerini geliştirirler. Canlandırmalardaki aktif rol alma ile hayal güçleri gelişir. Olaylara, sorunlara ve çözümlere dair sürekli bir düşünme ve sorgulama içerisindedirler.

Yaratıcı drama ile işlenen Türkçe derslerinde öğrenciler, dinlemenin dikkat gerektirdiğini, dinlerken de sorgulayıcı olunabileceğini fark ederler. Konuşurken betimlemeler yaparlar ve soru sormanın hikâyeyi anlamada büyük yol aldırdığını görürler. Okuma etkinlikleri ile yeni kahramanlar olarak hayat bulurlar. Hayal güçlerinin kendilerini götürdükleri yerin yazma becerilerini kuvvetlendirdiğini anlarlar. Yazmaya olan ilgi ve istekleri artar. Bir görselden hareketle bir hikâye, bir hikâyeden hareketle bir görsel oluştururlar. Yaratıcı drama sayesinde bir kitabın olaylarına, kahramanlarına farklı gözlerle bakar, canlandırmalardaki dramatik durumlara ve her bir probleme farklı bir çözüm üretirler.

Yaratıcı drama sürecinde her bir öğrencinin etkin olması ve sürecin farklı etkinliklerle tamamlanması Türkçe dersine yönelik sıkılganlık ve huzursuzluk duygularını azaltır. Onun yerine aktif olmaktan dolayı huzurlu, oyunlardan dolayı eğlenceli, rolden role girerek canlandırmalarda yer almaktan dolayı mutlu, canlandırmalara bağlı kalarak durum kötü, üzüntülü, korkulu ve şaşkın gerektiriyorsa bu duyguları hissederler. Sıradanlığın ve monotonluğun olmadığı bir ders ortamında öğrenmeye doğru kapılar açılır. Öğrenci yapabildiği inancını kazanarak öğrenmenin önünde duran korkularını yener. Daha istekle katılır, daha ilgiyle dinler ve öğrenmek için daha çok çaba harcar. Soru sorar, cevap arar, cevabı kendi zihninde bulma yollarını dener. Bu davranışları diğer arkadaşlarının dikkatini çeker. Onları etkiler. Öğrenme ortamı içinde gizli bir hareket başlar. Her bir öğrenci, önceki derslerde gösterdiği durağanlığı üstünden atar. Dikkatle dinler, anlamaya çalışır. Her bir fikre sorgulayıcı bakar. Arkadaşlarıyla konuşur, tartışır. Tartıştıkça okumadaki eksiklerini görür. Okumak, anlamak ve öğrenebilmek için kitaba sarılırlar. Okudukça canlandırmalarda yeni ve hayal güçlerinin sınırlarını zorladıkları çözümleri hep beraber üretirler. Birlikte hareket etmenin huzurunu yaşarlar, bunu uzun betimlemeler yaptıkları, tüm düşüncelerini, umutlarını, sorularını, cevaplarını, hüzünlerini, korkularını, mutluluklarını anlattıkları yazılara dökerler. Yüksek sesle düşüncelerini ifade ederler, bundan gurur duyarlar. Sonrasında gelecek dersi heyecan ve merakla beklerler.

Yaratıcı drama yöntemiyle işlenen Türkçe derslerinde oluşturulan bu sınıf ortamının öğrencilerin Türkçe dersine yönelik tutumlarını olumlu etkilediği söylenebilir. Çünkü derslerde sınıflarda oluşturulan olumlu atmosfer öğrencilerin derse karşı olan ilgi ve isteklerini arttırır. Yapılan araştırmalarda da yaratıcı drama yönteminin Türkçe derslerinde öğrencilerin dil becerilerine yönelik ilgi, istek ve tutumlarını arttırdığı ortaya konmuştur (Ataman, 2006; Erdoğan, 2012; Kırmızı, 2008; Stowe, 2001).

Ayrıca araştırmada öğrenci görüşlerinden elde edilen sonuçlar nicel bulguları destekler niteliktedir. Öğrenciler, yaratıcı drama yöntemi ile işledikleri derste sıkılmadıklarını, tam tersi her bir arkadaşları da dahil olmak üzere her birinin derse katıldığını ve bundan zevk aldıklarını belirtmişlerdir. Türkçe dersinin diğer yöntem ve tekniklerle işlemek yerine yaratıcı drama süreci ile işlenmesini tercih etmişlerdir. Öğrenciler yaratıcı drama sürecinde uygulamanın başından sonuna kadar bizzat uygulamanın içinde yer almışlar, sıkılma ve huzursuzluk gibi duygular yerine mutluluk, sevinç, heyecan, merak, üzüntü, şaşkınlık gibi birçok duyguyu aynı anda yaşamışlardır. Yaratıcı dramanın öğrenciyi merkeze alan yapısı sayesinde öğrenciler her etkinlikte yaparak yaşayarak öğrenme firsatı bulmuşlardır. Türkçe derslerinin ilgi, merak ve istekle gelmesini beklediklerini ifade etmişlerdir. 
Yapılan araştırmalarda da öğrencilerin yaratıcı dramayla gerçekleştirilen etkinliklere ilişkin olumlu görüşlere sahip oldukları ortaya konmuştur (Ataman, 2006; Erdoğan, 2012).

Araştırmada elde edilen sonuçlar 1şığında, ilkokullarda Türkçe öğretimine yönelik şu öneriler getirilebilir:

1. Türkçe dersindeki metinlerin işlenmesinde yaratıcı drama yönteminden yararlanılmalıdir.

2. Türkçe öğretiminde rol oynama, doğaçlama ve rol içinde yazma gibi öğrencinin hayal gücünü geliştiren ve düşünmeye sevk eden etkinliklere daha çok yer verilmelidir.

3. Benzer araştırmalar farklı sınıf düzeylerinde ve öğrencilerin dil becerilerine yönelik tutumlarıyla ilgili yapılabilir.

\section{Kaynakça}

Adıgüzel, H. Ö. (2006). Yaratııı drama kavramı, bileşenleri ve aşamaları. Yaratıcı Drama Dergisi. 1 (1), 17-30. Adıgüzel, Ö. (2010). Ĕgitimde yaratıcı drama. Natürel Yayınları, Ankara.

Aktaş Arnas, Y. Cömertpay B. ve Sofu, H. (2007). Altı yaş grubu çocukların dil kullanımına yaratıcı dramanın etkisi. Yaratıcı Drama Dergisi, 1 (3-4), 7-26.

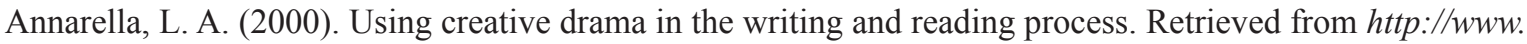
eric.ed.gov/PDFS/ED445358.pdf

Arieli, B. (2007). The integration of creative drama into science teaching. Doctoral of dissertation, Kansas State University, Manhattan.

Ataman, M. (2006). Yaratıcı drama sürecinde yaratıcı yazma. Yaratıcı Drama Dergisi, 1 (1), 75-88

Aykaç, M. (2011). Türkçe öğretiminde çocuk edebiyatı metinleriyle kurgulanan yaratıcı drama etkinliklerinin anlatma becerisine etkisi. Yayımlanmamış doktora tezi, Ankara Üniversitesi Eğitim Bilimleri Enstitüsü Eğitimin Kültürel Temelleri Ana Bilim Dalı Güzel Sanatlar Eğitimi Programı, Ankara.

Aykaç, N. ve Ulubey, Ö. (2008). Yaratıcı drama yöntemi ile yapılandırmacılık ilişkisinin 2005 MEB ilköğretim programlarında değerlendirilmesi. Yaratıcı Drama Dergisi, 3 (5), 25-45.

Baldwin, P. (2009). School improvement through drama. London: Network Continuum.

Baldwin, P. (2008). The primary drama handbook. London: SAGE Publications.

Brooks, J. G. ve Brooks, M. G. (1998). In Search of Understanding: The Constructivist Classrooms. Alexandria. VA: The Association for Supervision and Curriculum Development.

Büyüköztürk, Ş., Çakmak, E. K., Akgün, Ö. E., Karadeniz, Ş. ve Demirel, F. (2009). Bilimsel araştırma yöntemleri. Ankara: Pegem Akademi Yayınları.

Cresswell, J. W. (2008). Educational research. New Jersey: Pearson Education Inc.

Creswell, J. W., and Plano-Clark, V. L. (2007). Designing and conducting mixed methods research. (1th Edition). USA: Sage Publications.

Erdem, A. R. ve Gözüküçük, M. (2013). İlköğretim 3. 4. ve 5. sınıf öğrencilerinin Türkçe dersine yönelik motivasyonları ve tutumları arasındaki ilişki. Pegem Eğitim ve Öğretim Dergisi, 3(2), 13-24.

Erdoğan, T. (2011). Sınıf öğretmenlerinin Türkçe derslerinde yaratıcı drama yöntemini kullanma durumlarının incelenmesi. Yaratıcı Drama Dergisi, 6 (12), 23-38.

Erdoğan, T. (2012). Sinıf ögretmeni adaylarıyla yaratıcı drama sürecinde yaratıcı yazma. Çağdaş Drama Derneği Bitirme Projesi, Ankara.

Erdoğan, T. (2013). Türkçe öğretiminde yaratıcı drama uygulamaları. Ankara: Eğiten Kitap.

Fraenkel, J. R. ve Wallen, N. E. (2006). How to design and evaluate research in education. New york: McGraw-Hill Companies. 
Furman, L. (1990). Creative drama handbook and role play guide. Colorado: Pioneer Drama Service Inc.

Güneş, F. (2009). Türkçe öğretiminde günümüz gelişmeleri ve yapılandırmacı yaklaşım. Mustafa Kemal Üniversitesi Sosyal Bilimler Enstitüsü Dergisi, 6 (11), 1-21.

Karateke, E. (2006). Yaratıcı dramanın ilköğretim II. kademede 6.sını öğrencilerinin yazılı anlatım becerilerine olan etkisi. Yayımlanmamış yüksek lisans tezi, Mustafa Kemal Üniversitesi, Hatay.

Kaya Güler, İ. (2008). İlköğretim dördüncü sınıf Türkçe dersinde, yaratıcı dramanın etkililiği. Yayımlanmamış yüksek lisans tezi, 19 Mayıs Üniversitesi Eğitim Bilimleri Enstitüsü, Samsun.

Kırmızı, F. S. (2008). Türkçe öğretiminde yaratıcı drama yönteminin tutum ve okuduğunu anlama stratejileri üzerindeki etkisi. Pamukkale Üniversitesi Eğitim Fakültesi Dergisi, 1 (23), 95-109.

Maio ve Augoustinos, (2005). Psychology. Hewstone, M., Fincham, F. D. ve Foster, J. (Ed.). Blackwell Publishing.

McMillan, J., and Schumaher, S. (2001). Research in education a conceptual introduction. New Jersey: Pearson Education.

MEB. (2009). İlköğretim Türkçe dersi öğretim programı ve kılavuzu. Ankara: MEB Yayınları.

Stowe, A. (2001). Using drama to improve creative writing. Retrieved from http://www.ntrp.org.uk/sites/all/ documents/Stowe.pdf 12 April 2012.

Üstündağ, T. (2004). Yaratıcı drama öğretmeninin günlüğü. Ankara: PegemA Yayıncılık.

Yıldırım, A. ve Şimşek, H. (2006). Sosyal bilimlerde nitel araştırma yöntemleri. Ankara: Seçkin Yayıncılık.

Yılmaz, M. (2008). Türkçede okuduğunu anlama becerilerini geliştirme yolları. Mustafa Kemal Üniversitesi Sosyal Bilimler Enstitüsü Dergisi, 5/9, 131-139. 


\section{Ek: Atölye Planı Örneği (Beşinci Oturum)}

Ders: Türkçe

Tema: Sağlık ve Çevre

Grup: Mehmet Koçar İlkokulu 2-B Sınıfı Öğrencileri, 22 kişi (12 Kız, 10 Erkek)

Süre: 180 Dakika

Mekân: Mehmet Koçar İlkokulu Çok Amaçlı Çalışma Salonu

Yöntem: Yaratıcı drama

Teknikler: Rol oynama, doğaçlama, beyin Fırtınası, donuk imge

Araç ve Gereçler: Aytül Akal'ın "Ormandaki Apartman" adlı kitabı, 30 adet A4 kağıdı, kalemler, bant, pastel ve kuru boyalar.

\section{Kazanımlar}

1. Konuşmalarında betimlemeler yapar.

2. Konuşmasını görsel sunuyla destekler.

3. Olayları oluş sırasına göre yazar.

\section{Süreç}

\section{A. Hazırlık ve Isınma \\ 1. Etkinlik}

Katılımcılar üçerli grup olur, yan yana dururlar. İki katılımcı gönüllü olarak grupların dışında kalır ve biri kaçan diğeri de kovalayan rolündedir. Gönüllü katılımcıdan biri(kaçan) kendisine bir ev ararken üçerli grup olan arkadaşlarından birinin yanına gelir. Onun gelmesiyle grup dört kişilik olmuştur. Grubun diğer yanındaki katılımcı artık dışarıda kalır. Ebe, kendisini yakalamadan başka bir ev bulmak için kaçar. Başka bir üçlü gruba dahil olmak üzere kaçar. Ebe ise kaçanı yakalamak için kovalar ve kendine bir yer bulmak ister.

\section{Etkinlik}

Lider, katılımcılara bazı sorular sorar ve bir yönerge verir: "Hayvanlar arasında kendimize benzettiğimiz/ kendi davranış ya da huylarımız ile eşleştirdiğimiz bir hayvan var mı? Yani bir hayvanın özelliğinin sizde de olduğunu düşünüyor musunuz? Ya da hareketlerini ve bazı özelliklerini çok sevdiğiniz bir hayvan var mı? Neler seçtiniz, hangi hayvanın rolüne girdiniz, lütfen söylemeyiniz. Şimdi o hayvan nasıl yürür, nasıl hareket eder, buna dikkat ederek o hayvan rolüne giriniz ve o hayvan gibi yürüyünüz. O hayvan gibi hareket ediniz. Birazdan bir arkadaşınızın adını söyleyeceğim. Adını söylediğıim arkadaş, belirlediği hayvanın hareketlerini yapacak. Onun hareketlerini gözlemleyerek o hayvanın kim olduğunu tahmin ediniz.” Katılımcılar çeşitli hayvan yürüyüşleri ve hareketleri gösterir, ardından bir katılımcı da o hayvanı tahmin eder, tahminini sözlü ifade eder.

\section{Etkinlik}

Katılımcılar, hayvan rolündedirler ve ikili olurlar. Eşler kol kola girerler. Eşlerden birinin gözleri kapalıdır, diğer eşin gözleri açıktır. Gözleri açık olan eş, gözleri kapalı olan eşini kendi evine götürür ve ona evini betimler. Sonra gözleri kapalı olan eş, gözleri açık olan eşin betimlediği evi anlatır. Roller değişir, etkinlik devam eder.

\section{Etkinlik (Beyin Furtınası)}

Katılımcılara beyin fırtınası tekniği üzerine bilgi verilir. Sorular sorulur: "Canlılar, nerede yaşarlar? Her canlının bir evi var mıdır? Bir yerin bir canlı için ev olduğunu nasıl anlarsınız? Bir yere ev demek için neler gereklidir? Bir evde yaşanabilmesi için neler olması gerekir? Bir evin somut bir şekilde elle tutulur, gözle görülür olması için neler gereklidir? Bir evde olmazsa olmaz ne olmalıdır? Ne olmazsa o evde yaşanılamaz?" Katılımcılar beyin firtınası tekniği ile bir evi oluşturan her tür şeyi söylerler. 


\section{B. Canlandirma}

\section{Etkinlik (Donuk İmge)}

Katılımcılar, ikili gruplara ayrılırlar. Az önceki etkinlikte seçtikleri hayvan rollerine geri dönerler. Lider, hayvanların yaşadıkları durumu belirtir:

Hiç birimiz evimizden memnun değiliz. Evden yana çeşitli sorunlarımız var. Sıkıntılı bir durum içindeyiz. Eşinizle birlikte evinizdeki sıkıntıları konuşunuz, lütfen.

İki eş konuşurken size iki arkadaş daha katıldı. Aynı konu hakkında konuştuğunuzu fark ettiniz. Tartışma tekrar başladı. Neden evlerinizden hoşnut değilsiniz? Sorun ne?

Bu sorunu nasıl çözümlemek gerekir? Tartışmaya devam ediniz. Sonrasında bir çözüm bulmaya çalışınız.

Katılımcılar, yapılan bu tartışmaları/konuşmaları donuk imge ile diğer arkadaşlarına gösterirler. Ard arda üç donuk imge yaparlar. İlk donuk imge, evlerinden hiç memnun olmadıkları anı; ikincisi kendilerine katılan diğer arkadaşlarınızın da aynı sorundan muzdarip olduğunu anladıkları anı; üçüncüsü de bu soruna bir çözüm bulduğunuz anı anlatır. Katılımcılar üç anı anlatan donuk imgeleri gösterirler.

\section{Etkinlik}

Katılımcılar, iki gruba ayrılırlar. Liderin kendilerine söylediği hayvanlardan -tavşan, köstebek, yılan, maymun, zürafa, fil-birini kendilerine rol alırlar. Rol almayan katılımcılar da kendilerine başka bir hayvanı rol seçerler. Katılımcılar, ormanda yaşayan bazı hayvanlar olarak kendi evlerinde değil, bir apartmanda yaşamaya karar verirler. Ancak apartmanı kendileri inşa edecektir. İş birliği içinde apartmanı inşa etme sürecini anlatan bir canlandırma yaparlar. Ancak bu canlandırmada sözlü ifade kullanmazlar.

Katılımcılar, öncelikle çember olurlar. Sırayla çemberin içine girerek inşaat yapım sürecinde bir iş̧ yaparmış gibi bir eylemi gösterirler. Çemberin içindeki hayvan eylemi gösterirken bir arkadaş role girer, ona ne yaptığını sorar. Çemberin içindeki katılımcı, yapmakta olduğu eylemin adını değil, bambaşka bir eylemi yaptı̆̆ını söyler.

Lider, gruba etkinliğin anlaşılması için bir örnek verir: “”’-Boya yapma eylemi sergilerken benim soracağım: "Ne Yapıyorsun?"sorusuna "Ne yapıyorum, görmüyor musun? Toprak kazıyorum"”" diye yaptığınızın dışında, başka bir eylemin adını söyleyiniz." Canlandırmalar başlar. Lider, role girerek katılımcılara ne yaptıklarını sorar ve cevaplarını dinler. Ardından etkinliği katılımcılar devam ettirir.

\section{Etkinlik}

Apartmana taşınacak hayvanlar olarak lider, katılımcılara bir yönerge verir: "Evet yeni eviniz oturulmaya hazır. Taşınma vaktinde sıra. Sizler, uzunca bir süre evinizden şikayetçi oldunuz. Sonrasında evinden rahatsız olan sadece siz değilmişsiniz, bunu arkadaşlarınızla konuşurken fark ettiniz. Bu sorunu çözmek için bir çözüm buldunuz. Ormandaki evlerinizi terk ederek daha mutlu olacağınızı düşündüğünüz bir apartman inşa etmeye karar verdiniz. Arkadaşlarınızla hep birlikte bir apartman inşa ettiniz. Bu apartmana taşınmak üzere son kez ormandaki evinize gittiniz. Eşyalarınızı topladınız. Ormandaki evinizden çıkacak ve yeni apartmandaki yeni dairenize taşınacaksınız. Hangi duyguyu yanınızda götürüyorsunuz? Neler hayal ediyor, neler hissediyorsunuz? İçinizden hangi duyguyu/düşünceyi geçiriyorsanız lütfen yüksek sesle ve anlaşılır bir şekilde söyleyiniz ve yürüyerek apartmanınızın önüne geliniz." Katılımcılar yönergeye uygun olarak bir duyguyu/düşünceyi yüksek sesle ve anlaş1lır bir şekilde ifade ederler.

\section{Etkinlik}

Katılımcılar, kanguru, zürafa, timsah, balık, köstebek, kaplumbağa, tavşan ve fil olmak üzere sekiz gruba ayrılırlar. Kangurular evi, zürafalar evi, timsahlar evi, balıklar evi, köstebekler evi, kaplumbağalar evi, tavşanlar evi, filler evi olarak evlerine yerleşirler. Lider, her bir gruba birer kağıt verir. Katılımcılar, oturdukları evi, apartmanın bir katını anlatan bir resim çizerler. Sonra katılımcılar, çizdikleri evlerini, apartman katlarını üst üste koyarak birleştirirler ve apartmanın bütünsel resmi ortaya çıkar. Bu resmi apartmanın girişine asarlar. 


\section{Etkinlik}

Katılımcılara, etkinlikle ilgili durum anlatılır: "Çeşitli duygularla apartmanınızın önüne geldiniz. Şimdi iki gruba ayrılınız ve bu iki gruptan her birinde yeni hayvanlar olarak roller alacaksınız ve eşyalarınızı toplayarak yeni evlerinize, yani yeni apartman dairenize taşınacaksınız. Alacağınız rollere siz grup içinde karar verin lütfen, rolleriniz ise şunlar: Fil, tavşan, zürafa, köstebek, kaplumbağa, kanguru, tilki, balık ve timsah. Gruplarda fazla olan var ise, onlarda apartmanda alabilecekleri bir göreve uygun olarak kendilerine bir rol belirleyebilirler. Her biriniz rollerinizi seçtiyseniz, şimdi taşınma vakti. Lütfen eşyalarınızı alarak apartmanda bir daireye yerleşiniz. Kangurular evi, zürafalar evi, timsahlar evi, balıklar evi, köstebekler evi, kaplumbağalar evi, tavşanlar evi, filler evi olarak kapılarımıza küçük isimlikler astınız."

Katılımcılar, evlerine girerek ev hallerini anlatan bir canlandırma yaparlar. Canlandırmada, katılımcılar, aldıkları rollere uygun olarak bu evlerde nasıl yaşıyorlar? Yeni evleri ve yeni yaşantıları ne şekilde? Hayatları hangi duygu ve düşüncelerle sürüyor? bu noktalara dikkat ederler. Konuşmalar sırasında açık, anlaşılır ifadelerle ve yüksek sesle konuşurlar.

\section{Değerlendirme}

\section{Etkinlik}

Katılımcılar birer günlük alırlar. Apartmanın inşaatına karar verdikleri andan itibaren bugüne kadar yaşadıklarını açıklayıcı örnekler vererek günlüklerine yazarlar. Duygu ve düşüncelerini, yaşadıkları olayları oluş sırasına göre anlatırlar. 